\title{
ORGANIZACIJSKA KLIMA U FUNKCIJI UNAPRJEĐENJA MENADŽMENTA LJUDSKIH RESURSA
}

\author{
ORGANIZATIONAL CLIMATE IN THE FUNCTION OF \\ HUMAN RESOURCE MANAGEMENT IMPROVEMENT
}

\section{Bogdanović Mario}

Ekonomski fakultet Sveučilišta u Splitu, Cvite Fiskovića 5, 21000 Split, Republika Hrvatska

(C) MESTE NGO

\section{Sažetak:}

Ovim radom elaborira se koncept organizacijske klime i njegov odnos s menadžmentom ljudskih resursa. Prvo se razrješavaju uočene teorijske nekonzistentnosti pojmovne, sadržajne, istraživačke $i$ korisničke problematike. Zatim se prikazuju glavni istraživački pristupi i rezultati istraživanja organizacijske klime. $U$ kontekstu unaprjeđenja menadžmenta ljudskih resursa $i$ organizacijske djelotvornosti, utvrđene su potencijalne koristi od upravljanja organizacijskom klimom. Utvrđena je suštinska povezanost organizacijske klime s menadžmentom ljudskih resursa jer organizacijska klima može biti tretirana kao posebna funkcija ili praksa menadžmenta ljudskih resursa, ali se također može smatrati posljedicom svih praksi menadžmenta $i$ menadžmenta ljudskih resursa, odnosno jednim od pokazatelja njihove uspješnosti. Tako je pružen uvid u kompleksno područje upravljanja organizacijskom klimom poslovne organizacije u kontekstu unaprjeđenja menadžmenta ljudskih resursa.

\section{Ključne reči:}

menadžment ljudskih resursa, organizacijska djelotvornost, organizacijska klima, organizacijska kultura

\begin{abstract}
:
This paper elaborates the concept of organizational climate and its relationship with human resource management. First of all, theoretical inconsistencies of concept, content, research and application issues will be resolved. After that, the main research approaches and results in the area of organizational climate are presented. In the context of human resource management and organizational efficacy improvement, the potential benefits of organizational climate management have been determined. Further on, it is determined the basic connection of organizational climate with human resource management because organizational climate can be treated as special function or practice of human resource management, but also it can be treated as a consequence of all the management and human resource management practices, i.e. one of the measures of its efficacy. Therefore, the paper gives the insight in the complex area of organizational climate management in business organization in the context of human resource management improvement.
\end{abstract}

Adresa autora:

Mario Bogdanović

麦=” mbogdan2011@gmail.com

\section{Keywwords:}

human resource management, organizational efficacy, organizational climate, organizational culture 


\section{Uvod}

Koncept organizacijske klime ili jednostavno klime popularan je pojam kako u svakodnevnom govoru ${ }^{1}$, tako i u društvenim istraživanjima. ${ }^{2} \quad \mathrm{Za}$ organizacijsku klimu se počinju zanimati sve vrste organizacija zbog sve obimnijeg istraživačkog supstrata koji sugerira da organizacijska sredina (kontekst) u kojem se odvijaju svi organizacijski procesi, a socijalni procesi napose, bitno utječe na kvalitetu tih procesa. Naime u odgovoru na sve veće zahtjeve organizacijske okoline postaje razvidno da svi djelatnici organizacije trebaju biti zainteresirani za međusobnu suradnju, nalaženje, upotrebu i koordinaciju ljudskih i materijalnih resursa. Tako jačanjem uloge ljudskog resursa u ekonomici organizacije, jača i spoznaja da je ljudski resurs ključan i nezamijenjiv čimbenik organizacijske djelotvornosti (u okvirima koje se javlja posebna znanstvena disciplina menadžmenta ljudskih resursa), te se ujedno kao istraživačkoznanstveno područje i poslovna potreba organizacija javlja koncept organizacijske klime.

\footnotetext{
${ }^{1}$ Kada se u svakodnevnom govoru općenito želi reći da u organizaciji nešto ne funkcionira onda se obično kaže: „Loša je tamo klima", što bi se moglo konkretizirati kao neodgovarajuća organizacija rada, neodgovarajući međuljudski odnosi, neodgovarajući odnosi menadžmenta i zaposlenika (neprimjereno vođenje), neprimjeren sustav menadžmenta ljudskih resursa (zapošljavanja, radnog opterećenja, ocjenjivanja, sustava nagrađivanja, kontroliranja i slično), ali i psihološke percepcije netrpeljivosti, nepoštenja, nejednakosti, nepravednosti, neodgovornosti, zavisti, oholosti, nesolidarnosti, nejasnoće uloga, nepovjerenja, sumnjičavosti (...), dakle misli se da u organizaciji općenito vlada neki organizacijski nesklad, nered, nezadovoljstvo (...).

2 Organizacijska klima ima dugu povijest u području industrijske i organizacijske psihologije. Prva referenca u kojoj se ovaj konstrukt eksplicitno spominje datira iz 1939., kada su Lewin, Lippit i White objavili rad o eksperimantalnom kreiranju socijalnih klima u dječačkim grupama. Konstrukt organizacijske klime razvija se kasnih pedesetih i šezdesetih godina prošlog stoljeća u okviru istraživanja industrijskih organizacija. Također, intenzivnije istraživanje organizacijske klime veže se i za koncept organizacijske kulture (vrlo blizak i po nekim karakteristikama/autorima istovjetan ili sadržan u konceptu organizacijske klime) i pionirski rad Pettigrewa ("On studing Organizational Cultures", 1979., prema Schneider i dr. 1990., 14)., koji je inače označio paradigmatsku prekretnicu u realociranju temeljnih čimbenika poslovnog uspjeha (od znanstvenog menadžmenta, organizacijske strukture, korporacijske strategije do naposlijetku organizacijske kulture). Organizacijska kultura (dakle i sadržaji organizacijske klime) 1981. uvedena je kao sveučilišni kolegij na prestižni Harvard, te je do danas dobila status temeljnog činitelja uspješnosti poslovnih organizacija i konkurentske prednosti.
}

Pritom je znanstveni cilj dublja spoznaja koncepta i utvrđivanje uzročno-posljedičnih veza i odnosa sa ciljnim organizacijskim varijablama (etiološki model), a poslovni (praktični) pozitivno, odnosno optimalno organizacijsko ozračje ili djelotvoran organizacijski kontekst koji će afirmirati djelotvornost menadžmenta ljudskih resursa. Tako djelotvorna organizacijska klima postaje sve zanimljiviji, ali i potrebniji interni organizacijski čimbenik za sve organizirane sustave koji imaju ljudske resurse, a naročito one, koji teže izvrsnosti ili konkretnije konkurentskoj prednosti (Noe i dr., 2006). Posljedično tome, posljednjih desetljeća u menadžmentu vođenja ${ }^{3}$ (engl. leadershipa), također jača spoznaja i svijest da organizacijska sredina (kontekst, milje) u kojem se zbivaju svi interni organizacijski procesi, značajno utječe na kvalitetu tih procesa, posredno ili neposredno unaprjeđujući organizacijsku djelotvornost. Organizacijska klima naime utječe na organizacijske i psihološke procese komunikacija, rješavanja problema, odlučivanja, rješavanja konflikata, učenja, motivacije, zadovoljstva poslom, organizacijskog blagostanja te tako ima važan utjecaj na efikasnost i produktivnost organizacije, ali i na njezinu inovativnost $\mathrm{i}$ sposobnost promjene (Sušanj, 2005). Stoga je organizacijska klima nezaobilazna u djelotvornom menadžmentu ljudskih resursa. Organizacijska klima osim toga ima dugotrajan i neprekidan utjecaj tako da niti jedan odvojeni događaj u organizaciji ne proizvodi dugoročniji utjecaj na individualno mišljenje, osjećanje i ponašanje od nje, ona djeluje svakodnevno stvarajući naročitu psihološku atmosferu, ona je sveprožimajući i trajni organizacijski element, stoga je od naročitog značaja za razumijevanje organizacijskog ponašanja i organizacijskog života (Ekvall, 1987). Uloga i značaj organizacijske klime $u$ organizaciji može se sagledavati i u okviru poslovnih funkcija poduzeća $^{4}$, gdje se organizacijska klima može smatrati i posebno važnim rezultatom

\footnotetext{
${ }^{3}$ Disciplina menadžment sadržajno se tretira kroz funkcije menadžmenta. Različiti autori navode različiti broj funkcija menadžmenta, a one se u osnovi mogu svesti na četiri/pet osnovnih: planiranje, organiziranje, usmjeravanje (motiviranje i vođenje, upravljanje ljudskim resursima) i kontrolu.

${ }^{4}$ Poslovne funkcije poduzeća mogu se podijeliti na osnovne: nabava, proizvodnja, prodaja i pomoćne: logistika, računovodstvo i financije, marketing, menadžment ljudskih resursa i ostale funkcije kao potpora osnovnoj djelatnosti poduzeća.
} 
menadžmenta ljudskih resursa, i internog marketinga ${ }^{5}$ kao važnih funkcija u odvijanju internih poslovnih procesa. Organizacijska klima se tako tiče kompleksnog pitanja efikasnog upravljanja ljudskim resursima i ljudima $u$ organizaciji. ${ }^{6}$ Sukladno navedenom organizacijska klima je iznimno važan interni čimbenik i pokazatelj interne djelotvornosti organizacije, što ne podupiru samo zdravorazumska opažanja nego i empirijske studije. Kao složena mjera ukupnog organizacijskog konteksta, organizacijska klima je tako važna mjera kvalitete rada menadžmenta, napose u funkciji organiziranja rada i vođenja (odnosno rada s ljudima), ali i organizacijske funkcije menadžmenta ljudskih resursa, jer je jedan od važnih zadataka menadžmenta ljudskih resursa organizacije stvaranje adekvatne (primjerene) organizacijske klime (Bahtijarević-Šiber, 1999). Također je i sama organizacijska klima važan utjecajni čimbenik na funkcionalnost menadžmenta ljudskih resursa. Organizacijska klima je tako važan organizacijski koncept koji se pobliže može odrediti kao skup svih onih aspekata interne organizacijske situacije koji su zaposlenicima bitni odnosno značajni, te tako utječu na kognicije, emocije i ponašanje zaposlenika u organizaciji, pa se klima postavlja kao jedan od najvažnijih nematerijalnih, psihosocijalnih čimbenika funkcioniranja i razvoja organizacije (Sušanj, 2005). Pritom se općenito smatra da je to na iskustvu zasnovan, multidimenzionalan, relativno trajan, percepcijski fenomen koji je zajednički članovima neke

\footnotetext{
${ }^{5}$ Interni marketing predstavlja uvođenje i primjenu marketinga prema vlastitim ljudskim resursima. Naime uspjeh prema klijentima/potrošačima bitno je određen uspjehom marketinga unutar organizacije. Prema marketinškoj koncepciji ciljni tržišni segment internog marketinga su zaposlenici, pa je filozofija internog marketinga: prodaja poslova i zadataka svojim zaposlenicima.

${ }^{6}$ Upravljanje ljudskim resursima u užem smislu predstavlja tehnički dio menadžmenta ljudskih resursa (analiza radnih mjesta, planiranje ljudskih resursa, regrutiranje, selekcija, uvođenje tj. orijentacija u posao, obuka, obrazovanje i razvoj karijere, kompenzacije, materijalne strategije motiviranja, radni odnosi, unaprjeđenje uvjeta rada i života zaposlenika, organizacija kadrovske funkcije i slično, a upravljanje ljudima odnosi se na interpersonalni dio, odnosno vođenje u užem smislu, motiviranje (nematerijalne strategije motiviranja), upravljanje grupnim i interpersonalnim odnosima, upravljanje konfliktima, moćima, promjenama i slično. Menadžment ljudskih resursa u širem smislu pored tehničkog dijela uključuje i interpersonalni dio, odnosno menadžement vođenja (engl. leadership).
}

konkretne organizacijske jedinice (Koys \& De Cotiis, 1991). Organizacijska klima je važna i za organizacijsku promjenu, danas neizostavan činitelj organizacijske uspješnosti. Naime, bilo koja strategija organizacijskog preustroja zahtijeva strategiju promjene u organizacijskim psihosocijalnim ambijentima, dakle mora početi $s$ promjenom klime. U situaciji neprimjerenih odnosa na relaciji menadžment-zaposlenici, predviđene strategije organizacije i menadžerske prakse neće zaživjeti na zamišljen i poželjan način. Organizacijska klima je i činitelj unaprjeđenja organizacijskih procesa koji su u samoj biti realizacije strategije i projekata organizacije. Stoga ako se želi poboljšati organizacijsku učinkovitost, ili je pripremiti za organizacijsku promjenu bitno je utvrditi kakva klima vlada u organizaciji (koji su elementi dobri, koji su granični, a koji ne zadovoljavaju s obzirom na ciljne željene parametre te na temelju utvrđenog stanja vršiti poboljšanja). Kao bitni elementi stvaranja djelotvorne organizacijske klime mogu se spomenuti: dobra organizacija rada, zajedničko planiranje, dobri međuljudski odnosi i organizacijski sklad, osjećaj pripadnosti organizaciji, jasni ciljevi, visoka razina očekivanja, red, rad, odgovornost i ljubav. ${ }^{7}$ Pritom su dobra organizacija rada i dobri međuljudski odnosi dva temeljna stupa djelotvorne klime. Ukoliko organizacijska klima nije djelotvorna, zamišljeni organizacijski ciljevi, projekti i zadaci pokazat će slabije ostvarenje od očekivanog ili se uopće neće realizirati na predviđeni način. Primjerice, zbog činjenice da organizacije nisu

\footnotetext{
${ }^{7}$ Tko god radi u organizaciji s djelotvornom radnom klimom uobičajeno razvija prema toj organizaciji i određene pozitivne osjećaje, primjerice osjećaj ponosa i povećanu odgovornost (moralni imperativ). U takvoj klimi postaje normalni kulturaln obrazac, dati dio sebe (rad i doprinos) te promovirati svoju organizaciju u eksterijeru. Djelotvorna organizacijska klima povećava vjerojatnost povećane odgovornosti prema organizaciji. Stoga nije neobično da zaposlenici trpe negativna čuvstva i bihevioralne smetnje ukoliko organizacija poslovno stagnira, ukoliko se unutar nje ili po nju događaju nepovoljni događaji. Sve to može rezultirati osobnom žalošću, potresenošću i depresijom. Smrt organizacije (stečaj) za vjernog djelatnika po težini stresa može biti usporediva sa posljedicama smrti člana kućanstva ili bliže rodbine. Stoga je djelotvorna organizacijska klima onaj organizacijski čimbenik koji daje smisao, motivaciju i vitalitet, nemoguće ju je nadomijestiti nečim drugim, kao što kvalitetnu hranu nije moguće zamijeniti nečim drugim (primjerice zrakom, vodom ili čovjeku neprimjerenim nutritijentima), a da čovjek odnosno analogno organizacija dugoročno funkcionira dobro.
} 
uspostavile djelotvornu organizacijsku klimu u projektnim timovima propada oko $4 / 5$ projekata (Srića, 2008). Stoga se čini da je za organizacijski uspjeh, bez obzira na vrstu organizacije (profitnu, neprofitnu), za dobro funkcioniranje ljudi $u$ organizaciji (na različitim razinama agregacije), djelotvorna organizacijska klima „conditio sine qua non" efikasne organizacije. Usprkos navedenom, istraživanja i sustavno upravljanje organizacijskom klimom rijetka su pojava u organizacijskoj praksi, uglavnom zbog složenosti i nejednoznačne operacionalizacije samog koncepta i različitih načina istraživanja i mjerenja. ${ }^{8}$ Zbog važnosti $i$ potencijalne korisnosti djelotvorne organizacijske klime $s$ jedne strane, ali i složenosti i teškoća u istraživanju i primjeni $s$ druge strane, svrha ovog rada je jasno prikazati koncept organizacijske klime, eksplicirati ju za potrebe istraživačkog i praktičnog djelovanja (upravljanja organizacijskom klimom) u kontekstu unaprjeđenja menadžmenta ljudskih resursa.

\section{Eksplikacija pojma, uloge i modela organizacijske klime u dosadašnjim istraživačkim naporima}

Organizacijska klima upućuje na internu organizacijsku okolinu (organizaciju sustava rada i odnose na relaciji menadžment-zaposlenici) koja znatnim dijelom određuje i ograničava ponašanje članova organizacije pa je činitelj organizacijskog ponašanja. Tako se općenito smatra da pojedinac reagira na određenu situaciju na temelju značenja koje ta situacija za njega ima (Sušanj, 2005, 11), pa je opća organizacijska situacija sinonim za konstrukt organizacijske klime. $U$ samom istraživačkom definiranju konstrukta organizacijske klime u kontekstu opće organizacijske situacije prisutna su dva temeljno različita pristupa: realistički/objektivni i subjektivni/fenomenološki (Ekvall, 1987, 177). Prema objektivističkom poimanju organizacijska klima egzistira kao organizacijski realitet, pa se može definirati kao tipično ponašanje, stavovi i osjećaji u organizaciji; uzorci koji su konzistentni kod različitih individua u

\footnotetext{
8 Kad koncept ima mnogo različitih konceptualizacija, operacionalizacija (načina, mogućnosti, razina mjerenja) kada ga ne krasi iznimna jasnoća, onda se često događa situacija da brojnim ljudima zapravo nema nikakvog značenja, i da ga stoga nerado sustavno istražuju i praktično primjenjuju. Jednostavnost je često nužna pretpostavka primjene.
}

istim situacijama. Prema toj perspektivi organizacijska klima je organizacijski atribut koji postoji nezavisno od percepcija i apercepcija njezinih članova, pa je objektivni dio organizacijske realnosti. Prema subjektivnom pristupu organizacijska klima se smatra perceptivnim i kognitivnim strukturiranjem organizacijske situacije od strane članova organizacije. $U$ organizaciji naime postoji kontinuirani tijek događanja, akcija, rutina i procesa koje pojedinci pokušavaju interpretirati tako da im organizacijska okolina postane razumljivija. Tako kreiraju svoju „kognitivnu mapu“, koja im pomaže u davanju značenja onoga što vide i što čuju. Kada članovi organizacije međusobno kontaktiraju događa se razmjena iskustava i apercepcija, njihove osobne kognitivne mape se konfrontiraju i međusobno modificiraju. Tako se u organizaciji percipiraju i interpretiraju događaji. Prema takvom pristupu organizacijska klima se sastoji od običnih apercepcija koje evoluiraju kroz vrijeme i događaje. Bez obzira na pristup u svakoj organizaciji postoje relativno stabilni psihološki uvjeti, koji se smatraju kao objektivna realnost koja je „u zraku“, ili se preferira prikloniti subjektivističkom motrištu, smatrajući organizacijsku klimu kognitivnom mapom psiholoških uvjeta koji su članovi organizacije zajedno kreirali i koju dijele. lako je ova razlika teorijski jasna, na empirijskoj strani ova razlikovanja nisu odvojena, jer različiti istraživački izvještaji često ne razlikuju ova gledišta. Većina studija organizacijske klime koristi upitnike kojima se ispituju članovi organizacije velikim brojem pitanja o uvjetima u organizaciji. Pitanja su ista bez obzira koji se pristup adaptira, realistički ili fenomenološki. Individualni rezultati se tada agregiraju da bi se dobili rezultati skala organizacijske klime čitave organizacije, ili za dio organizacije kome je opis namijenjen. Organizacijska klima se stoga može promatrati svojstvom organizacije, konglomeratom stavova, osjećaja, ponašanja koji karakteriziraju život u organizaciji (Ekvall, 1996, 105), ili jednostavnije kao percepcija o tome koliko organizacija ispunjava tekuća očekivanja svojih članova (Deshpande i Webster, 1989. prema Wooldridge i Minksy, 2002, 31). Široko je određena kao „skupna percepcija događanja u organizaciji“, a uže kao „zajednička percepcija organizacijske politike, izvedbe, procedure te njihovog formalnog i neformalnog provođenja“, pa tako odražava osobnu orijentaciju organizacije (povezana je dakle s kulturom) te je 
proizvod sustava vrijednosti i normi (Schneider i dr. 1990, 78). Organizacijsku klimu se može shvatiti i kao radnu psihosocijalnu atmosferu izraženu iskustvom i shvaćanjima zaposlenih. ${ }^{9}$

U pojmovnom razjašnjenju važnu ulogu ima razgraničenje organizacijske klime od drugih vrlo sličnih, a različitih koncepata. Tu treba napraviti dvostruku distinkciju:

- istraživači govore o više kategorija klime pa treba razlikovati organizacijsku klimu od psihološke klime, agregiranih klima (subklima, kolektivna klima, socijalna klima, radna klima) i facetne klime (klima za različite kontekste);

- istraživači uz organizacijsku klimu istražuju i druge slične koncepte ponekad in ne razlikujući ili ih poistovjećujući pa treba napraviti distinkciju između pojmova kao što su: organizacijka kultura, stavovi prema radu, organizacijsko samopoštovanje, organizacijski sklad (kohezija).

\subsection{Razlika organizacijske klime i psihološke klime}

Prema Jamesu i Jonesu (1974) i Zvonareviću (1989) razlika između klime kao organizacijskog svojstva i klime kao individualnog svojstva označava razliku organizacijske i psihološke klime. Koncept organizacijske klime tako svoju operacionalnu definiciju treba bazirati na prosječnim vrijednostima percepcija i vrijednosti članova organizacije, a koncept psihološke klime trebao bi se koristiti u studijama gdje se koriste individualni opisi kao jedinica analize, bez pokušaja agregacija i stvaranja organizacijske mjere. Stoga se može reći da $\mathrm{u}$ organizaciji postoji manja ili veća razlika između psihološke i organizacijske klime, pa to može biti predmetom istraživanja „tzv. klimatskog jaza“ (Ekvall, 1996). Pritom se studira svaka razlika između pojedine psihološke klime i organizacijske klime kao i efekt te razlike na individualne stavove, osjećaje i ponašanje u organizaciji. Dakle, psihološka klima (individualna percepcija $\mathrm{i}$ opis organizacijske situacije) predstavlja neagregirane

\footnotetext{
${ }^{9}$ Istraživači organizacijske klime nisu se mnogo bavili njenim definiranjem i elaboriranjem već su se više bavili empirijskom provjerom unutarnje i vanjske valjanosti konstrukta (Litwin i Stringer, 1968; Schneider i Barlett, 1970. prema Sušanj, 2005. 14). To je u skladu s istraživačkom koncepcijom da definicije uglavnom služe za komunikaciju s laicima ili kao pomoćno sredstvo istraživača.
}

individualne percepcije subjektivne okoline, i bliži je konceptu zadovoljstva poslom (afektivna reakcija na organizacijsku situaciju) nego organizacijskoj klimi, dok je organizacijska klima karakteristika socijalnih sustava.

\subsection{Razlika organizacijske klime i agregiranih klima}

Agregirana klima je skup individualnih percepcija objedinjenih na nekoj formalnoj hijerarhijskoj razini (primjerice radna grupa, odjel, poslovni sektor, hijerarhijska razina ili organizacija u cjelini). Ovdje je racionalna pretpostavka da određena grupa unutar organizacije ima značajno različitu klimu od neke druge grupe. Stoga se kaže da je agregirana klima temeljena na statistički utvrđenim razlikama među odjelima odnosno različitim grupama pojedinaca iz jedne organizacije. Tu se onda i razvija polemika među organizacijskim znanstvenicima: jedni tvrde da klimu treba promatrati na razini čitave organizacije (onda je to organizacijska klima), drugi smatraju da ako se želi razumijeti ponašanje treba istraživati klime subsustava (agregirane klime na različitim razinama agregacije), treći tvrde da postoji i ukupna organizacijska klima i organizacijske subklime. Treba istaći da istraživanja daju potporu svim ovim stavovima $\mathrm{i}$ da organizacije formiraju različite klime, vjerojatno prema radnim grupama, poslovnim funkcijama i hijerarhijskim pozicijama (Schneider i dr., 1990). Joyce i Slocum (1984) uvode koncept „kolektivne klime“i pod time misle klimu koja je uobičajena grupi osoba u organizaciji, bez obzira da li pripadaju nekom obliku, jedinici u formalnom smislu. Oni ne agregiraju sve opise klime (jer spajanje različitih opisa nema istu spoznajnu snagu) već spajaju samo one iskaze individua čiji su opisi organizacijske situacije slični, te tako pripadaju konstruktu "kolektivne klime“. Dakle, kolektivna klima je rezultat agregacije samo sličnih opisa organizacijske situacije. Socijalna pak klima predstavlja agregaciju individualnih klima, na nekoj razini agragacije bez obzira na slaganje njezinih članova. Radna klima može se smatrati dijelom organizacijske klime koja se odnosi na percepciju rada, organizacije rada i radnih zadataka u organizaciji. Ona se može smatrati radnim elanom, radnom atmosferom, a u realnosti je povezana sa ostalim klimama. Što se tiče međuodnosa organizacijske klime i pojedinca može se navesti njegovu dvosmjernost: $s$ jedne strane svaki je djelatnik organizacije pod utjecajem 
organizacijske klime, odnosno opće radne i psihosocijalne atmosfere $u$ organizaciji, a s druge je i sam aktivni čimbenik stvaranja te iste organizacijske klime pa je pojam organizacijske klime važan za objašnjenje i razumijevanje organizacijskog ponašanja.

\subsection{Razlika organizacijske klime i facetne (kontekstualne) klime}

Istraživači klime govore i o organizacijskim klimama u specifičnim sferama (kontekstualno specifične ili facetne klime), pa se počinje govoriti primjerice i uslužnoj klimi, klimi brižnosti, inovativnoj klimi, sigurnosnoj klimi (...). Primjerice, dvije organizacije mogu imati sličnu sigurnosnu klimu, a različitu klimu uslužnosti. Ovakav pristup organizacijskoj klimi podrazumijeva više instrumenata kojima bi se mjerili različiti aspekti organizacijskih klima, a u istraživanju organizacijske klime tendencija je da se koristi općenitiji klimatski upitnik. Nekoliko in je opisano u literaturi, a individualni istraživači obično koriste neki od njih. Nedostatak istraživanja specifičnih klima je da je to u suprotnosti s znanstvenim utvrđivanjem utjecaja nezavisnih varijabli na organizacijsku klimu (cilj je utvrditi kakva je pojedina facetna klima), a prednost je dobivanje specijalnog instrumenta za mjerenje različitih aspekata klime kojih može biti i više od dvadeset. Dakle prema facetnom viđenju, organizacijska klima predstavljala bi različite aspekte/facete klime $\mathrm{u}$ organizaciji.

\subsection{Razlika organizacijske klime i kulture}

Organizacijska klima i kultura razlikuju se prvenstveno u vrsti kognicija koje se koriste za njihovo definiranje (Sušanj, 2005). Organizacijska klima je prvenstveno desktriptivan fenomen (temelji se na deskriptivnim uvjerenjima, a organizacijska kultura je prvenstveno kauzalan i normativan fenomen (temelji se na kauzalnim i normativnim uvjerenjima). Deskriptivna uvjerenja definiraju ono što jest iz perspektive pojedinca (opisi organizacijske situacije iz perspektive pojedinca). Kauzalna uvjerenja definiraju zašto je nešto takvo kakvo je i način predviđanja budućih događaja (zašto je organizacijska situacija takva kakva je i kako predvidjeti njezinu budućnost). Normativna uvjerenja definiraju kakva bi organizacijska situacija trebala biti (idealitet). Upravo iz tog razloga različite vrste kognitivnih uvjerenja dobar su temelj za razlikovanje organizacijske klime i kulture. Organizacijska klima više naglašava način na koji pojedinac doživljava svoju socijalnu i inu okolinu, dok organizacijska kultura ističe proces stvaranja te socijalne okoline od neke skupine pojedinaca (neke razine agregacije). Usustavljeno znanje o različitosti koncepata prikazano je u tablici 1.

\section{Tablica 1. Temeljne razlike koncepata organizacijske klime i kulture (Priređeno prema Sušanj, 2005).}

\begin{tabular}{|l|l||}
\hline ORGANIZACIJSKA KLIMA & ORGANIZACIJSKA KULTURA \\
\hline \hline Deskriptivna uvjerenja & Kauzalna i normativna uvjerenja \\
\hline \hline $\begin{array}{l}\text { Fenomen individualnih psiholoških } \\
\text { procesa }\end{array}$ & Fenomen na razini određene socijalne jedinice \\
\hline \hline $\begin{array}{l}\text { Relativno trajna karakteristika } \\
\text { organizacije }\end{array}$ & Stabilnija, dugoročnija karakteristika organizacije \\
\hline \hline $\begin{array}{l}\text { Podrazumijeva ahistorijsko snimanje } \\
\text { stanja organizacije }\end{array}$ & $\begin{array}{l}\text { Podrazumijeva historijski pristup proučavanju } \\
\text { organizacije }\end{array}$ \\
\hline \hline $\begin{array}{l}\text { Koristi kvantitativnu metodologiju } \\
\text { istraživanja }\end{array}$ & Koristi kvalitativnu metodologiju istraživanja \\
\hline \hline $\begin{array}{l}\text { Psihologijski konstrukt (njezine } \\
\text { manifestacije na opažajnoj razini) }\end{array}$ & $\begin{array}{l}\text { Antropološki i sociološki konstrukt (dublje vrijednosti } \\
\text { i temeljne pretpostavke) }\end{array}$ \\
\hline \hline
\end{tabular}




\subsection{Razlika organizacijske klime, stavova prema radu, organizacijskog samopoštovanja i organizacijskog sklada}

Rezimirajući navedene odrednice organizacijske klime može se reći da organizacijska klima neizostavno predstavlja misli i doživljaje djelatnika u svezi s poslom koji obavljaju, pa se dio organizacijske klime može obuhvaćati ispitivanjem sličnih varijabli: stavova prema radu, organizacijskog samopoštovanja, organizacijskog sklada. Naime, iako je organizacijska klima desktiptivan fenomen (deskriptivna uvjerenja), nije ju moguće potpuno izolirati od evaluativnih, kauzalnih i normativnih uvjerenja koja svakako imaju utjecaj na njeno formiranje (jer ovisi o ljudima). Kao i kod različitosti organizacijske klime od organizacijske kulture, temeljna razlika prema stavovima prema radu, organizacijskom samopoštovanju i organizacijskom skladu je u tzv. evaluativnim uvjerenjima. Evaluacija redovito podrazumijeva čuvstveni odnos prema predmetu stava. Stav se obično predstavlja kao afektivna orijentacija prema objektu stava (McCormick \& Ilgen, 1996, 308). Stavovi prema radu određuju način na koji će zaposlenici doživljavati svoju radnu okolinu. Teoretičari i praktičari najčešće istražuju tri vrste stavova prema radu: zadovoljstvo poslom, zaokupljenost poslom i pripadnost organizaciji. Zadovoljstvo poslom je opći afektivni odnos pojedinca prema svom poslu i cjelokupnoj radnoj situaciji, dakle predstavlja evaluativna uvjerenja prema predmetu stava. To je psihološka dispozicija ljudi prema poslu kojeg obavljaju (Schultz \& Schultz, 1986, 327). Ono se obično odnosi na stavove pojedinačnog zaposlenika, ali isto tako se može odnositi i na stav određene grupe. Također, zadovoljstvo poslom može obuhvaćati samo jedan aspekt posla ili se može shvatiti kao sveobuhvatni stav. To znači da zaposlenici mogu biti zadovoljni s jednim aspektom posla (primjerice suradnici) a nezadovoljni s drugim (primjerice plaća). Stoga se praktično obično ispituje više takvih zadovoljstava kao što su primjerice varijable: zadovoljstvo samim poslom, zadovoljstvo menedžerima, zadovoljstvo plaćom, zadovoljstvo suradnicima i zadovoljstvo napredovanjem (...). Zadovoljstvo poslom rezultat je mišljenja radnika o svim za njega relevantnim, intrinzičnim i ekstrinzičnim aspektima posla (Šverko, 1991, 48), stoga jasno imaju važan obol u formiranju organizacijske klime. Zaokupljenost poslom je stupanj u kojem se pojedinac psihološki identificira sa svojim poslom, odnosno s važnošću posla u njegovoj sveukupnoj slici o sebi, odnosno psihološka identifikacija osobe s njezinim radom, odnosno kao stupanj u kojem je radna situacija centralna za osobu i njen identitet (Lawler i Hall prema Šverko, 1991, 25). Zaokupljenost poslom (evaluativno uvjerenje) tako iako nije organizacijska klima (deskriptivno uvjerenje) ukazuje se kao bitan čimbenik u njenom formiranju. Sasvim će drugačiju organizacijsku klimu stvoriti pojedinci zaokupljeni poslom od onih koje taj posao ne zanima, čiji su interesi esencijalno drugdje. Stoga iako je zaokupljenost poslom važan dio organizacijske klime, kao konstrukt $s$ njom nije istovjetna. Pripadnost organizaciji se definira kao stupanj do kojeg se pojedinac identificira $s$ organizacijom $u$ kojoj radi i koliko je uključen u njeno funkcioniranje, a obuhvaća): a) vjerovanje u organizacijske ciljeve i vrijednosti, te njihovo prihvaćanje, b) spremnost ulaganja napora u obavljanju posla za organizaciju, c) želju da se ostane članom organizacije (Porter $i$ dr., 1974). Mowday i dr. (prema Broke, Russell i Price, 1988) pretpostavili su da je predanost organizaciji širi koncept koji se odnosi na osjećaj pripadnosti ili odanosti organizaciji kao cjelini, a ne na specifičan posao $s$ naglaskom na sukladnost individualnih $\mathrm{i}$ organizacijskih ciljeva. Po njima pripadnost organizaciji odnosi se na to koliko se zaposleni identificiraju s organizacijom u kojoj rade, te na to koliko i dalje žele raditi u njoj. Pripadnost organizaciji također je evalutativno uvjerenje, pa iako nije organizacijska klima, važan je čimbenik u formiranju pozitivne i poticajne organizacijske klime. Samopoštovanje (engl. self-esteem) je termin koji se najčešće koristi da bi se izrazilo globalno vrednovanje samog sebe (evaluativno uvjerenje). Pod samopoštovanjem Coopersmith (prema Schultzu, 1986) razumijeva evaluaciju kojom pojedinac odražava stav prihvaćanja ili neprihvaćanja samoga sebe. Ta evaluacija upućuje na stupanj uvjerenja u vlastite sposobnosti, važnost, uspješnost ili vrijednost. Koncept o sebi važan je aspekt ličnosti koji znatno utječe na ljudsko funkcioniranje i ponašanje. On predstavlja integrativni sklop stavova koje pojedinac ima o sebi. Sadrži evaluativnu i deskriptivnu komponentu. Organizacijsko samopoštovanje ima bitnu ulogu u formiranju organizacijske klime iako se kao koncept od organizacijske klime razlikuje. Vrlo sličan koncept organizacijskoj klimi s kojom se lako može 
poistovjetiti i zamijeniti je organizacijski sklad (kohezija). Kako bi razlučili ova dva pojma treba reći da je organizacijska kohezija dio organizacijske klime, ali naravno nije ukupna organizacijska klima. Osim toga, organizacijski sklad (kohezija) ima i afektivnu, dakle evaluativnu komponentu, pa se i po vrsti uvjerenja razlikuje od organizacijske klime. Prema Golemanu (1997) organizacijski sklad je važan faktor u postizanju maksimalne kvalitete proizvoda određene skupine, a to je stupanj do kojeg su njezini članovi u stanju stvoriti stanje unutrašnjeg sklada koje im omogućava korištenje punog potencijala svakog pojedinog člana. Prema navedenom autoru zaključuje se da skladni odnosi omogućuju skupini da maksimalno iskoristi sposobnosti svojih najkreativnijih i najnadarenijih članova. Organizacijski sklad može se istraživati kao dio organizacijske klime. U kontekstu efikasnog funkcioniranja radnih timova (djelotvorne organizacijske klime također se spominje pojam sinergije koja upućuje na pojam organizacijskog sklada. Naime, sinergija je stanje koje postiže radni tim kada su međusobni odnosi snažni, članovi tima visoko motivirani $i$ međuovisni te je izgrađeno zajedničko povjerenje. Sinergija nije neočekivan fenomen već je rezultat kumulativnog ulaganja u radne timove (Wong, 2007, 203-204). Sinergija je također pojam koji se može tretirati kao rezultat djelotvorne organizacijske klime.

Što se tiče odnosa organizacijske klime sa drugim organizacijskim varijablama (modela klime) treba reći da danas još ne postoji jedan sveobuhvatni model etiologije organizacijske klime jer bi takav morao biti ekstremno kompleksan (brojne, različite varijable $u$ različitim interakcijama ${ }^{10}$ utječu na organizacijsku klimu). Rutine, pravila, procedure, strategije, politike, i fizička okolina - svi ti čimbenici provociraju reakcije uključenih ljudi. Reakcije u obliku ponašanja, osjećaja, stavova čine organizacijsku klimu u njenom realnom smislu, ali i ljudi su dio organizacijske situacije (organizacijski kontekst modelira ljudske reakcije). Osoba $X$ je čimbenik okoline $Y$ i obrnuto (okolina $Y$ je čimbenik osobe $\mathrm{X}$ ). Također je i interakcija između članova organizacije važan dio klime. Stoga su dosadašnji

\footnotetext{
${ }^{10}$ Primjerice stupanj decentralizacije može generirati sasvim različite klime $u$ dvije iste organizacije, jer dobna struktura radne snage ne mora biti ista, a ona može presudno utjecati na klimu.
}

modeli uglavnom opća pojednostavljenja, ili pak uzimaju samo jedan segment općeg modela koji nastoje objasniti. Payne i Pugh (1976.) tako pojednostavljeno baziraju svoj model organizacijske klime na ideji da strukturalne organizacijske varijable najvećim djelom determiniraju klimu. Otkrili su dvije temeljne varijable koje objašnjavaju više jasnih korelacija $s$ organizacijskom klimom: decentralizacija i veličina organizacije. De Cook i dr. (1985.) prema Ekvall (1996.) u modelu organizacijske klime dokazuju i druge uzročne faktore: organizacijski kontekst, organizacijska struktura, politika prema kadrovima i menadžerska strategija.

U svim dosadašnjim modelima organizacijske klime još uvijek treba biti razjašnjena uloga osobaartikulatora, kreatora i deskriptora klime. Vanjski faktori kao što su tehnologija, tržište, uvjeti vlasništva, vrsta imovine (aktive) u organizaciji (...) također mogu imati modificirajući utjecaj na odnose između drugih (korelacijskih ili uzročnih) varijabli i organizacijske klime. Od internih organizacijskih faktora svakako bi strateški menadžement (načini suočavanja i ovladavanja okolinom) i osobni menadžment (vođenje) organizacije trebalo direktno uključiti u jedan takav cjeloviti objašnjavajući model organizacijske klime. Jedan od postojećih plauzibilnih općih kontekstualnih klimatskih modela prikazan je u shemi 1.

$U$ priloženom modelu opća kultura (kultura šire okoline) djeluje na organizacijsku kulturu koja pak uz pomoć menadžmenta ljudskih resursa ${ }^{11}$ (njezinih praksi) djeluje na organizacijsku klimu.

Organizacijska klima pak djeluje na psihološka stanja zaposlenika (kognitivna, emocionalnomotivacijska, vrijednosna) koja se odražavaju u ponašanjima $i$ onda konačno $u$ organizacijskoj uspješnosti. Iz predočenog postaje razvidno da je unaprjeđenje organizacijske učinkovitosti i optimalno korištenje ljudskih resursa organizacije snažno povezano $\mathrm{s}$ konceptom organizacijske klime, koja je praktično redoviti moderator svih organizacijskih procesa.

\footnotetext{
${ }^{11}$ Menadžment ljudskih resursa je disciplina koja se sržno bavi politikom ljudskih resursa u organizaciji, dakle uređuje odnose na relaciji menadžment-zaposlenici (Delarue i dr., 2008., 143-144.).
} 


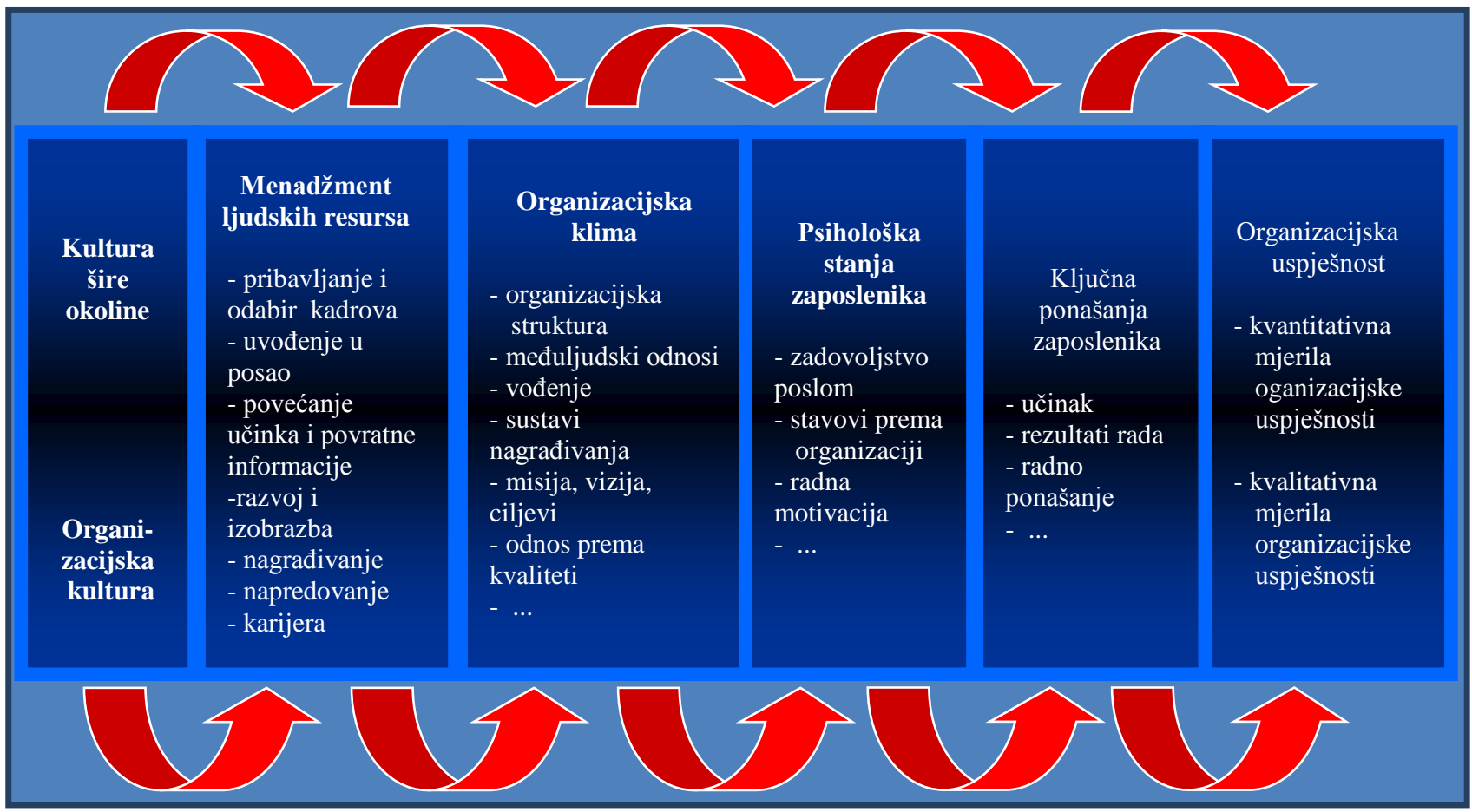

Shema 1. Organizacijska klima unutar šireg sustava (Koopelman,Brief \& Guzzo, 1990 prema Šegotić, Jaković \& Sušanj, 2006)

U jednom ovakvom općem organizacijskom modelu, organizacijska klima se može vidjeti kao interventna varijabla u procesu između inputa $\mathrm{i}$ outputa, a na taj proces ima modificirajući utjecaj. Organizacijska klima tako utječe na psihološke procese, potičući/degradirajući ključna ponašanja zaposlenika te tako ostvaruje utjecaj na rezultate organizacijskih operacija. Također se može tvrditi da organizacijska klima određuje rezultate koje će organizacija biti u mogućnosti ostvariti od svojih resursa, primjerice u obliku profita, inovacija ili zadovoljstva poslom. Jedan od modela organizacijske klime koji organizacijsku klimu povezuje sa organizacijskom strukturom, vrijednostima (organizacijska kultura), interfunkcionalnom koordinacijom i organizacijskom učinkovitošću prikazan je u shemi 2.

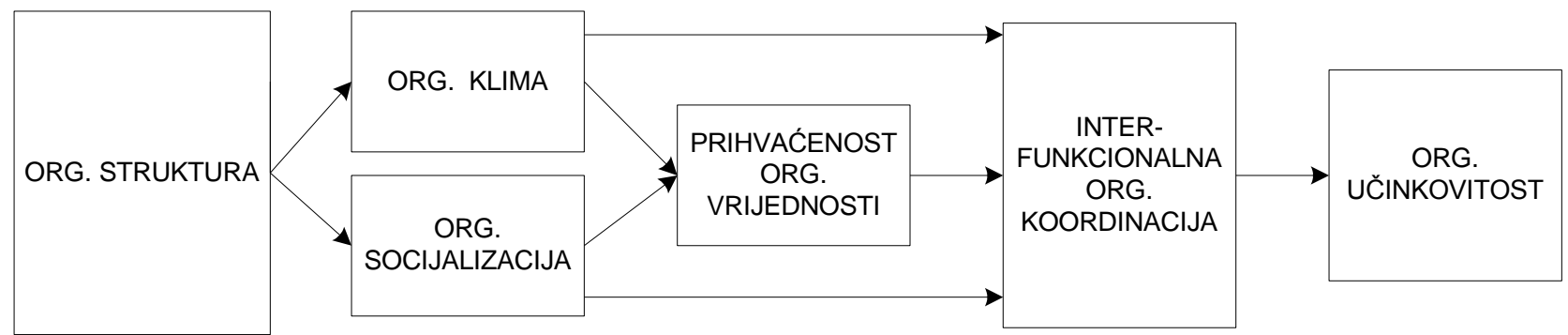

Shema 2. Model odnosa organizacijske klime s drugim internim organizacijskim varijablama (Woolridge \& Minsky, 2002)

$\mathrm{Na}$ shemi 2. je vidljivo da organizacijska struktura može igrati ulogu organizacijske kulture jer vrši modifikaciju ponašanja $s$ konačnim ciljem interfunkcionalne koordinacije i organizacijske djelotvornosti. Stoga se organizacijska struktura ukazuje kao važan faktor organizacijske klime, 
budući da su predočena istraživanja i nalazi potvrdili efekte strukture na medijacijske varijable (organizacijske klime, prihvaćenih organizacijskih vrijednosti, interfunkcionalne koordinacije) i zavisnih varijabli organizacijske učinkovitosti (Woolridge \& Minsky, 2002, 36).

Također, uz organizacijsku strukturu kao bitni utjecajni čimbenici koji nisu navedeni u modelu mogli bi se navesti misija i strategija te menadžment ljudskih resursa (Senge, 1990. prema Ivancevich, 1995, 8).

\section{Elementi organizacijske klime}

Istraživači još uvijek nisu jednoznačno odredili od kojih se elemenata sastoji organizacijska klima. Rezultati istraživanja ukazuju da je to različiti skup deriviranih faktora, odnosno dimenzija organizacijske klime. Jedan od mogućih integralnih općih sadržaja organizacijske klime nude Wilson, Webb, Corbet, 1994. (prema Pastuović, 1999, 561 562):

1. Organizacijska ekologija. Odnosi se na fizički i materijalni vid organizacije (zgrade, postrojenja, oprema, veličina, novčana sredstva);

2. Organizacijski kontekst (milje). Odnosi se na psihološke i demografske osobine menadžera i djelatnika kao što su obrazovanje, radno iskustvo, socioekonomski položaj, vrijednosna orijentacija i slično.

3. Socijalni sustav organizacije. Odnosi se na pravila prema kojima se trebaju ponašati društvene (socijalne) skupine u organizaciji (menadžeri, profesionalci, administrativci, izvršioci i slično).

4. Organizacijska kultura. ${ }^{12}$ Odnosi se na sustav vjerovanja i vrijednosti koje se očituju u obredima, ritualima, ceremonijama, običajima, odijevanju, grupnim normama privrženosti organizaciji, suradničkom ponašanju i kolektivnim očekivanjima.

Međutim iz činjenice različitih shvaćanja i pristupa istraživanju organizacijske klime, još uvijek nije jednoznačno utvrđeno od kojih se konkretnijih elemenata sastoji. Je li organizacijska klima nediferencirana suma percepcija ili se sastoji od

\footnotetext{
12 Treba reći da pojedini autori smatraju i obrnuto, odnosno organizacijsku klimu dijelom organizacijske kulture (primjerice, Armstrong, 1990).
}

facetno specifičnih klima? Muscinsky (1976, prema Sušanj, 2002) prema svojim istraživanjima pokazuje različit skup deriviranih faktora odnosno dimenzija organizacijske klime. lako postoji veći broj pokušaja da se pronađe zajednički nazivnik strukturi organizacijske klime u različitim tipovima organizacije najčešće se navode pet faktora organizacijske klime (Konrad i Kline, 1986.; Sušanj, 1987.; prema Sušanj, 2002): Struktura (osjećaj koji zaposlenici imaju o ograničenjima koja proizlaze iz organizacijske strukture i naglašavanja pravila, normi, propisa); Podrška i toplina (percipirana pomoć i podrška od strane rukovoditelja i drugih zaposlenika, te opći osjećaj o međuljudskim odnosima u organizaciji); Rizik (osjećaj o poželjnosti preuzimanja rizika u poslu i organizaciji); Identitet (opći doživljaj pripadnosti i lojalnosti organizaciji); Standardi (percipirana važnost postavljenih ciljeva standarda kvalitete i učinkovitosti)

Prema Quinn i Rohrbaughovom modelu organizacijske analize (Quinn \& Rohrbaugh, 1983), model organizacijske klime se sastoji od tri temeljne osi (dimenzije): prva os je vrijednosna dimenzija koja se odnosi na organizacijsko usmjerenje od internalnog (mikro) naglašavanja dobrobiti i razvitka ljudi $u$ organizaciji i eksternalnog (makro) naglašavanja dobrobiti i razvitka same organizacije. Druga os odnosi se na organizacijsku strukturu, od naglašavanja stabilnosti do naglašavanja fleksibilnosti. Treća os odnosi se na načine i ciljeve, od naglašavanja važnih procesa (planiranja i postizanja ciljeva) do naglašavanja ciljeva (završnih izlaza, primjerice proizvodnost). Kombinacijom ovih osi dobivena su četiri oblika organizacijskog ponašanja tj. klimatskih ozračja (shema 3) koji se podudaraju s četiri temeljne teorije organizacije: Human Relations Model u kojem je naglašena kohezija i moral, dok je cilj razvoj ljudskih potencijala (podrška); Open Systems Model naglašava fleksibilnost $i$ vještinu, a cilj je rast $i$ stjecanje potencijala organizacije (inovacije); Internal Process Model u kojem je naglašeno informiranje i komunikacija, a cilj je stabilnost i kontrola (pravila); Relation Goal Model gdje se naglašavaju planiranje i postizanje ciljeva, a cilj je proizvodnost i djelotvornost (ciljevi).

Moosova konceptualizacija organizacijske klime (Moos, 1974.; 1979.; 1986.; 1987) sastoji se od dimenzija odnosa, osobnog razvoja ili orijentacije prema cilju, te dimenzija održavanja i promjene 
sustava. Njegova konceptualizacija rezultat je istraživanja organizacijske klime u različitim organizacijskim miljeima (školskim ustanovama, studentskim domovima, psihijatarskim bolnicama, korekcijskim ustanovama za odrasle i malodobne delinkvente, obiteljima, radnom miljeu, vojnim ustanovama, psihoterapeutskim ustanovama i staračkim domovima).

\begin{tabular}{|c|c|c|c|}
\hline \multicolumn{4}{|c|}{ FLEKSIBILNOST } \\
\hline $\begin{array}{l}\text { Human } \\
\text { Relations } \\
\text { Model }\end{array}$ & PODRŠKA & INOVACIJA & $\begin{array}{l}\text { Open } \\
\text { System } \\
\text { Model }\end{array}$ \\
\hline \multirow{2}{*}{\multicolumn{2}{|c|}{ INTERNALNA ORIJENTACIJA }} & \multicolumn{2}{|c|}{ EKSTERNALNA ORIJENTACIJA } \\
\hline Internal & & & Rational \\
\hline Process & PRAVILA & CILJEVI & Goal \\
\hline Model & & & Model \\
\hline \multicolumn{4}{|c|}{ KONTROLA } \\
\hline
\end{tabular}

Shema 3. Pojednostavljen prikaz spacialnog modela organizacijske efikasnosti (Quinn \& Rohrbaugh, 1983)

Dimenzija odnosa opisuje kvalitetu i intenzitet odnosa među ljudima u određenoj sredini. Njima se procjenjuje opseg u kojem su ljudi uključeni u sredinu, u kojemu podupiru i pomažu jedni drugima, te $u$ kojem mogu slobodno $i$ otvoreno izražavati svoja mišljenja. Dimenzija osobnog razvoja ili orijentacija prema cilju odnosi se na temeljne ciljeve pojedine sredine, odnosno na način na koji okolina potiče ili onemogućava razvoj pojedinca. Dimenzija održavanja i promjene sustava mjeri opseg $u$ kojemu u danoj okolini vlada red, koliko je ona organizirana, koliko su jasna očekivanja od pojedinaca, koliko je stupanj kontrole, te koliko je okolina spremna na promjene. Dimenzije i njihovi opisi navedeni su u tablici 2.

James i James (1989, prema Sušanj, 2002) predlažu četiri empirijski utvrđena faktora organizacijske klime: 1. Podrška i facilitacija rukovoditelja; 2 . Stres vezan za ulogu i nedostatak harmonije; 3. Izazovnost posla i autonomija; 4. Kooperacija, toplina i prijateljstvo u radnoj grupi. Navedeni autori pokušavaju različita socijalna okruženja opisati pomoću manjeg broja faktora klime koji obično variraju od tri do šest. Stoga Schneider (1985) i Muschinsky (1976, prema Sušanj, 2002) opravdano zaključuju da su uzroci razlika u dobivenim faktorima u različitim organizacijskim uvijetima i događajima. Ako se organizacijska klima eksplicira kao percepcija radne okoline, teško se može očekivati da će jednak skup faktora postojati u različitim radnim okolinama gdje postoje specifični oblici organizacijske prakse i procesa. Stoga i Rousseau (1988) naglašava potrebu za preciznijom specifikacijom i operacionalizacijom konstrukta organizacijske klime. Istraživanja koja koriste pojam facetnospecifične organizacijske klime (primjerice, organizacijska klima koja se odnosi na klimu inovacija, sigurnost u radu ili pak klima usmjerena na pružanje usluga) predlažu da treba precizno odrediti vrstu organizacijske klime koju se ispituje. Ovakav pak pristup čini odmak od gledanja na organizacijsku klimu kao višedimenzionalni konstrukt (Rousseau, 1988). Tako istraživači navode sljedeće facete organizacijske organizacijske klime: 1. Klima organizacijske pravde; 2. Klima vodstva (leadershipa); 3. Klima interpersonalnog tretmana; 4. Klima različitosti; 5 . Klima demografske različitosti; 6 . Klima inovacija; 7. Klima kontinuiranog učenja; 8. Klima timskog rada; 9. Klima uslužnosti kupcima. Navedene klime iako konceptualno ne spadaju u organizacijsku klimu (u deskriptivna uvjerenja) još se u istraživanjima mogu nadopunjavati varijablama stavovima prema organizaciji (evaluativna uvjeranja) te se $u$ tom kontekstu spominju: 1. Zadovoljstvo poslom; 2. Posvećenost organizaciji (engl. commitment); 3. Organizacijska očekivanja; 4. Organizacijska fluktuacija; 5. Angažiranost na zadatku; 6 . Psihološko osnaženje (engl. empowerment) na radnom mjestu; 7. Organizacijski konflikti. 
Tablica 2. Elementi organizacijske klime prema modelu realne radne okoline (Moos, 1986).

\begin{tabular}{|l|l|}
\hline DIMENZIJA ODNOSA & OPIS SUBSKALE \\
\hline 1. Uključenost & opseg u kojem su djelatnici zainteresirani za, te predani svom poslu \\
\hline 2. Kolegijalna kohezija & $\begin{array}{l}\text { opseg u kojem se djelatnici ponašaju prijateljski i pružaju podršku } \\
\text { jedni drugima }\end{array}$ \\
\hline 3.Podrška rukovoditeljima & $\begin{array}{l}\text { opseg u kojem rukovoditelji pružaju podršku djelatnicima i potiču in } \\
\text { da si međusobno pomažu }\end{array}$ \\
\hline DIMENZIJA OSOBNOG RAZVOJA & \\
\hline 4. Autonomija & $\begin{array}{l}\text { opseg u kojem se djelatnike potiče da u svom radu budu nezavisni i } \\
\text { da se u radu oslanjaju na vlastite odluke }\end{array}$ \\
\hline 5. Orijentacija na zadatak & $\begin{array}{l}\text { stupanj naglašavanja dobrog planiranja aktivnosti, djelotvornosti i } \\
\text { izvršavanja radnih obaveza }\end{array}$ \\
\hline 6. Radni pritisak & $\begin{array}{l}\text { stupanj u kojem radni i vremenski pritisak dominiraju u radnom } \\
\text { miljeu }\end{array}$ \\
\hline $\begin{array}{l}\text { DIMENZIJA ODRŽAVANJA I } \\
\text { PROMJENE SUSTAVA }\end{array}$ & $\begin{array}{l}\text { opseg u kojem djelatnici znaju što mogu očekivati u svakodnevnoj } \\
\text { rutini i koliko su jasna pravila i propisi }\end{array}$ \\
\hline 7. Jasnoća & $\begin{array}{l}\text { opseg u kojem rukovoditelji koriste pravila i pritiske da bi držali } \\
\text { djelatnike pod kontrolom }\end{array}$ \\
\hline 8. Kontrola & stupanj naglašavanja raznolikosti, promjena i novih pristupa u radu \\
\hline 9. Inovativnost & opseg u kojem fizička okolina doprinosi ugodnom radnom ozračju \\
\hline 10. Fizički komfor &
\end{tabular}

Organizacijska klima se spominje i u kontekstu instrumenta za dijagnostiku vitalnih znakova organizacije (www.sixseconds.com/ovs.php, 2008). Spomenuti izvor navodi pet temeljnih faktora organizacijske klime uz jedan preklapajući koji je prisutan u svim dimenizijama (tj. organizacijsko povjerenje): 1. Odgovornost i dužnost (odgovara na pitanje jesu li zaposlenici motivirani preuzimati odgovornosti; 2. Suradnost i rješavanje problema (odgovara na pitanje da li ljudi međusobno komuniciraju i dijele informacije, te da li zajednički rješavaju probleme); 3. Percepcija vođenja (odgovara na pitanje razine privrženosti sljedbenika prema njihovim vođama te kako su percipirani od strane svojih sljedbenika); 4. Orijentacija na zadatak (odgovara na pitanje uključenosti u njihovu organizaciju, misiju i njezino provođenje, uz procjenu osjećaja pripadnosti organizaciji); 5 . Adaptacija na promjene, prilagodljivost, snalažljivost (odgovara na pitanje da li zaposlenici traže promjene i da li su spremni im se adaptirati); 6 . Povjerenje (odgovara na pitanje da li ljudi imaju smisao i vjeru u organizaciju i njene vođe, bave li se ljudi „zaštitom svojih leđa“ umjesto da daju maksimalni doprinos). Organizacijski znaci vitalnosti (djelotvorne organizacijske klime) povezuju se $s$ sljedećim organizacijskim varijablama: identifikacijom spremnosti, privrženosti i vještine promjeni; identifikacijom vrijednosti, emocionalnom inteligencijom i ponašanjima potrebnim za uspjeh; znakovima upozorenja menadžerima o potrebi i mogućnostima treninga, komunikaciji i razvoju; strategijom održivog razvoja. Prema navedenom izvoru navedene dimenzije kao nezavisne varijable objašnjavaju $57,7 \%$ organizacijske performanse (zavisne varijable izražene kao izvještaji samoefikasnosti u multiploj regresijskoj analizi). Iz navedenog pregleda strukture, elemenata $i$ načina dolaženja do dijagnostičkih podataka o organizacijskoj klimi, za zaključiti je da organizacijska klima sve više zaokuplja pažnju istraživača iz njene nesumnjivo važne heurističkoznanstvene uloge, ali i praktičnog smisla unaprijeđenja organizacijske djelotvornosti. 


\section{Djelotvorna organizacijska klima i njene potencijalne koristi u kontekstu unaprjeđenja menadžmenta ljudskih resursa}

lako nije moguće dati odgovor djelotvorne organizacijske klime za sve kontekste, općenito se djelotvorna organizacijska klima može shvatiti kao način mogućeg obogaćivanja rada, radnih uvjeta i ukupnog radnog ozračja u organizacijama, s nekom vizijom izvrsnosti. Tako je u općenitom smislu u djelotvornoj organizacijskoj klimi ugodna radna klima, prisutan je "duh" povjerenja, njeguju se visoke etičke vrijednosti i uvažava se dostojanstvo čovjeka. U takvoj se sredini svi manje-više osjećaju ugodno, posao je zadovoljstvo, a pozitivni radni rezultati postižu se takoreći nenapornom lakoćom. Iz obilježja djelotvorne organizacije (Peters i Waterman, 1982, Brajša, 1997, Bahtijarević-Šiber, 1999, Bieneck, 2006) mogu se izlučiti bitni elementi djelotvorne organizacijske klime za 21. stoljeće: klima lakog prihvaćanja promjena; participativnog, demokratskog upravljanja i tolerancije; neformalne komunikacije bez posrednika; timskog rada i odlučivanja; snažne vizije i entuzijazma; vrhunskih postignuća, stalnog rasta i razvoja, spontanosti, povjerenja, etičnosti, općenito poticajnih i motivirajućih psihosocijalnih radnih uvjeta. To je klima gdje vlada zajedničko povjerenje, međuzavisnost, odgovornost, vrednovanje individualnih razlika, transparentnost, učenje i priznanje (Wong, 2007, 48). U kreiranju dobre radne atmosfere menadžment treba slijediti pravila uljudnosti, dobrohotnosti i uslužnosti te pritom biti veseo, obziran, uljudan i od pomoći (Templar, 2011, 48). Uz te manje-više nematerijalne uvjete za koje nisu potrebna nikakva posebna dodatna materijalno-financijska ulaganja, može se mnogo učiniti na poboljšanju materijalnih radnih uvjeta koji bi trebali pogodovati čovjekovim osjetilima i prilagođenosti rada čovjeku. $U$ izgradnji radnih prostora trebalo bi težiti uporabi zdravih po mogućnosti prirodnih građevinskih elemenata, a $\mathrm{i}$ unutrašnjost se prostora može uz manja ulaganja, opremiti tako da bude funkcionalan (ergonomski) $i$ ugodan. Ako bi se mogao dati zorni opći idealni primjer djelotvorne organizacijske klime onda bi to bio znanstveno-futuristički serijal "Enterprise". ${ }^{13}$

${ }^{13}$ Organizacijska klima je toliko specifična za svaku organizaciju da se ne može naučiti posredno primjerice iz knjiga i/ili udžbenika, već isključivo neposredno u direktnoj interakciji
Neprimjerena (neadekvatna ili suboptimalna) organizacijska klima se sve češće povezuje s poslovno-ekonomskom neučinkovitošću, naročito $u$ poslovima gdje dominira intelektualna i kreativna komponenta $s$ tzv. radnicima znanja. Stoga takve kompanije sve veću pažnju usmjeruju na ovaj organizacijski fenomen. $U$ organizacijama gdje egzistira nepovoljna i ljudima neprimjerena organizacijska klima zaključuje se da je riječ o lošoj organizaciji i lošem menadžmentu, jer su njegovi učinci ne samo psihosocijalno već i poslovnoekonomski nepovoljni za organizaciju (smanjenje kvalitete i kvantitete učinka, smanjenje kreativnosti i sposobnosti rješavanja problema, sabotaža, napuštanje radnih mjesta, suboptimalna alokacija ljudskih resursa, zdravstveni problemi čija je negativna manifestacija mjerljiva putem apsentizma, povreda i nezgoda na radu, profesionalnih bolesti, te različitih bihevioralnih problema koji ometaju organizacijsku djelotvornost. Ulaganja u organizacijsku klimu (koja su najvećim dijelom socijalna ulaganja, a manjim dijelom su to materijalna ulaganja jer se tiču poboljšanja fizičkih radnih uvjeta) svakako treba doživljavati i tretirati kao investiciju. Stoga su aktivnosti usmjerene na djelotvornu organizacijsku klimu važan ekonomski zadatak poduzeća s sljedećim mogućim koristima:

\section{A. DIREKTNE KORIST}

A.1. Bolje korištenje organizacijskih kapaciteta (uz smanjen apsentizam i fluktuaciju bolje se može planirati i iskoristiti postojeći kapaciteti strojeva i opreme, ali i radni kapaciteti ljudskih resursa);

A.2. Poboljšana produktivnost (dobri radni uvjeti potiču produktivnost u kvalitativnom i kvantitativnom smislu. To je naročito vidljivo

\footnotetext{
sljudima. To je najzornije, prikazano u znanstvenofantastičnom serijalu "Star tracks", pa se kroz seriju uviđa da je uspješnost misije i pojedinih zadataka u organizaciji svemirskog broad "Enterprise" upravo u izravnoj i nezamijenjivoj funkciji $s$ organizacijskom klimom i organizacijskim skladom, hijerarhiji usprkos. Djelotvorna organizacijska klima pritom podržava, a ne narušava organizacijsku strukturu i njezino efikasno funkcioniranje. lako je futuristički, navedeni serijal iznimno dobro prikazuje vrstan menadžment ljudima (što nije isto što i menadžment ljudskim resursima jer se bavi samo funkcijom rukovođenja) organizacijskom klimom $s$ jasno prikazanim pozitivnim posljedicama pozitivne organizacijske klime, kao i povremenim posljedicama narušenog organizacijskog sklada.
} 
kod intelektualnih, odnosno informacijama zahtjevnih zanimanja);

A.3. Smanjenje apsentizma (smanjenje troškova uslijed gubitaka u proizvodnji);

A.4. Smanjivanje broja i težine nezgoda na radu i profesionalnih oboljenja (značajno poboljšanje sigurnosti vezano je uz poboljšane psihosocijalne tretmane, čiji je glavni efekt smanjenje inače za tretman iznimno skupih nezgoda, profesionalnih oboljenja, bihevioralnih smetnji).

\section{B. INDIREKTNE KORISTI}

B.1. Smanjivanje troškova zdravstvene i socijalne skrbi;

B.2. Produženje radne sposobnosti (kasniji odlazak u mirovinu).

\section{EMOCIONALNO-MOTIVACIJSKE KORISTI}

\section{C.1. Poboljšanje zadovoljstva poslom; \\ C.2. Poboljšanje radne atmosfere i osjećaja opće dobrobiti; \\ C.3. Poboljšanje komunikacije pojedinaca i grupa; \\ C.4. Poboljšanje vještina suočavanja sa stresom; \\ C.5. Poboljšanje motivacije.}

Spomenuta poboljšanja direktno se i indirektno reflektiraju na poboljšane performanse i kvalitetu organizacijskih procesa i rezultata, dakle konkurentnost.Temeljem navedenog može se ustvrditi da je organizacijska klima s poslovnoekonomskog gledišta strateški organizacijski čimbenik, čimbenik koji zaslužuje pažnju menadžmenta, a menadžementa ljudskih resursa napose, jer označava mogućnost značajnog unaprijeđenja poslovnih procesa, projekata i njihovih konačnih rezultata. Zapravo je organizacijska klima sadržajno i suštinski povezana s menadžementom ljudskih resursa, jer organizacijska klima može biti tretirana kao posebana funkcija ili praksa menadžmenta ljudskih resursa, ali se također može smatrati posljedicom svih ostalih praksi menadžmenta i menadžmenta ljudskih resursa, odnosno jednim od pokazatelja njihove uspješnosti. Naime, većina postojećih istraživanja ne može dokazati da investiranje u aktivnosti menadžementa ljudskih resursa uzrokuje superiorni financijski rezultat, jer ne mjere druge ključne elemente bitne za strateški uspjeh organizacije (primjerice organizacijska klima), pa ostaje neodgovoreno kako radne grupe i zaposlenici (organizacijska klima) utječu na ključne procese i rezultate (Cascio \& Boudreau, 2008, 16).

\section{ZAKLJUČCI}

Organizacijska klima je važan čimbenik za unaprjeđenje prakse menadžmenta ljudskih resursa jer utječe na organizacijske i psihološke procese komunikacija, rješavanja problema, odlučivanja, rješavanja konflikata, učenje, motivaciju, utječe na zadovoljstvo poslom, organizacijsko blagostanje, pa tako posredno i neposredno utječe na organizacijsku produktivnost i efikasnost. lako je iz organizacijskog iskustva i dosadašnjih istraživanja postalo koliko-toliko jasno da je koncept organizacijski važan, on je ujedno i vrlo složen i nejednoznačan (pojmovno, sadržajno, operacionalno). $U$ pojmovnom razjašnjenju i za olakšanu istraživačku djelatnost važnu ulogu ima razgraničenje organizacijske klime od drugih vrlo sličnih, a različitih koncepata. Stoga je izvršeno razlikovanje organizacijske klime od pojmova: 1) psihološke klime, agregiranih klima (subklima, kolektivna klima, socijalna klima, radna klima) i kontekstualnih klima (facetna klima); kao i 2) organizacijske kulture, stavova prema radu (zadovoljstvo poslom, zaokupljenost poslom i pripadnost organizaciji), organizacijskog samopoštovanja, organizacijskog sklada (kohezije). Naime, u istraživačkim izvješćima se ovi koncepti često preklapaju što dovodi do nejasnoća i nekonzistentnih zaključaka.

$\mathrm{U}$ radu su nadalje prezentirani neki sadržaji koncepta organizacijske klime koji se koriste $u$ istraživanju i praksi, te su predočena dva modela odnosa organizacijske klime $s$ drugim organizacijskim varijablama.

Eksplicirano je što je to djelotvorna organizacijska klima za 21. stoljeće (kakvoj organizacijskoj klimi treba težiti), a iz brojnih obilježja djelotvorne organizacije izlučeno je da bi to trebala biti organizacijska klima sa sljedećim karakteristikama: klima lakog prihvaćanja promjena; participativnog, demokratskog upravljanja i tolerancije; neformalne komunikacije bez posrednika; timskog rada i odlučivanja; snažne vizije i entuzijazma; vrhunskih postignuća; stalnog rasta i razvoja; spontanosti; povjerenja, etičnosti, i funkcionalnih radnih uvjeta. Navedene su i brojne potencijalne koristi od djelotvornog upravljanja organizacijskom klimom: 
1) Direktne koristi (bolje korištenje organizacijskih kapaciteta, poboljšana produktivnost, smanjenje apsentizma, smanjenje broja težine nezgoda na radu i profesionalnih oboljenja); 2) Indirektne (smanjivanje troškova zdravstvene i socijalne skrbi, produženje radne sposobnosti); 3) Emocionalnomotivacijske koristi (poboljšanje zadovoljstva poslom, poboljšanje radne atmosfere i osjećaja opće dobrobiti, poboljšanje komunikacije pojedinaca i grupa, poboljšanje vještina suočavanja sa stresom, poboljšanje motivacije).

Utvrđeno je da se organizacijska klima može tretirati kao posebana funkcija ili praksa menadžmenta ljudskih resursa, ali i kao posljedica svih ostalih praksi menadžmenta i menadžmenta ljudskih resursa, odnosno jednim od pokazatelja njihove uspješnosti.

Za rezimirati je da je organizacijska klima istraživački privlačan, ali i kompleksan istraživački predmet, tako da ima visoku heurističku vrijednost. Za praktičnu organizacijsku upotrebu važno je uočiti njezinu stratešku važnost za uspješan menadžement i organizaciju, naročito $u$ dijelu upravljanja ljudskim resursima i ljudima.

\section{Citirani radovi}

Armstrong, M. (1990), How to be an even better manager, London, Rogan Page.

Bahtijarević, Šiber, F. (1999), Management ljudskih potencijala, Zagreb, Golden marketing.

Bieneck, H. J. (ur.), (2006), The Economic Efficiency of Health and Safety at Work, Federal, Dortmund: Institute for Occupational Safety and Health.

Broke, P. P., Russell, D. W., Price J. L. (1988), Discriminant validation of measures of job satisfaction, job involvment and organizational commitment, Journal of Applied Psychology, 73: 139-145.

Cascio, W. F., Boudreau, J. W. (2008), Investing in people: Financial impact of human resource inititatives, New Jersey, Pearson Education, Inc., Publishing as FT Press.

Delarue, A., Van Hootegem, G. Procter, S., Burridge, M. (2008), Teamwork and organizational performance: A review of survey-based research, International Journal of Management Reviews, 10 (2): 127-148.

Ekvall, G. (1987), The climate methaphor in organizational theory. U: Bass, B. M., Drenth, P. J. D. (ur.), Advances in organizational psychology: An International review (str.177-190), Newbury Park, Sage Publication.

Ekvall, G. (1996), Organizational climate for creativity and inovation, European Journal of Work and Organizational Psychology, 5 (1):105-123.

Goleman, D. (1997), Emocionalna inteligencija na poslu, Zagreb, Mozaik knjiga.

Ivancevich, J. M. (1995), Human Resource Management, International Edition, IRWIN.

Joyce, W. F., Slocum, J. W (1984), Collective Climate: Agreement as a Basis for Defining Aggregate Climates in Organizations, Academy of Management Review, 27 (4): 721-742.

Kopelman, R. E., Brief, A. P., Guzzo, R. A. (1990), The role of climate and culture in productivity, U: B. Schneider (ed.) Organizational climate and culture, (282-318), San Francisco: Jossey-Bass.

Koys, D. J., DeCotiis, T. A. (1991), Inductive Measures of Psychological Climate, Human Relations, 44 (3): 265-285.

Lewin, K., Lippitt, R., White, R. K. (1939). Patterns of aggressive behaviour in experimentally created «social climates». Journal of Social Psychology, 10: 271-299.

Mc Cormik, E. J., Ilgen, D. (1992), Industrial and organizational psychology, Routhledge, Musselburgh.

Moos, R. H. (1974), Evaluating Treatment Environments: A Social Ecological Approach, New York: John Willey and sons.

Moos, R. H. (1979), Evaluating Educational Enviroments: Procedures, methods, findings and policy implications, San Francisco, CA: Jossey-Bass Publishers.

Moos, R. H. (1986), Work Enviroment Scale manual, 2nd ed., Palo Alto, CA: Consulting Psychologists Press.

Moos, R.H. (1987), The Social Climate Scales: A users guide. Palo Alto, CA: Consulting Psychologistis Press.

Noe, R. A., Hollenbeck, J. R., Gerhart, B., Wright, P. M. (2006), Menadžment ljudskih potencijala: postizanje konkurentske prednosti, Zagreb, Mate d. o.o..

Pastuović, N. (1999), Edukologija: integrativna znanost o sustavu cjeloživotnog obrazovanja i odgoja, Zagreb, Znamen. 


\section{Bogdanović M. Organizacijska klima i menadžment ljudskih resursa}

\section{FBIM Transactions Vol.1 No.1 pp. 1-17}

Payne, R. L. i Pugh, D. S. (1976), Organizational structure and climate. U: Dunnette, M. D. (ur.), Handbook of Industrial and Organizational Psychology (str. 1125-1173), Chicago, Rand McNally.

Porter, L. W., Steers, R. M., Mowday, R. T., Boulian, P. V.(1974), Organizational commitment, job satisfaction and turnover among psychiatric technicians, Journal of Applied Psychology, 59: 603-609.

Quinn, R. E., Rohrbaugh, J. (1983), A spatial model of efectiveness criteria: Towards a competing values aproach to organizational analysis, Management Science, 29 (3): 363-377.

Rousseau, D. M. (1988), The construcition of climate in organizational research. U: Cooper, C. L., Robertson, I. (ur.), International Rewiev of Indurstrial and Organizational Psychology (str. 39-158), New York, John Wiley and Sons Ltd.

Schneider, B. i dr. (1990), Organizational climate and culture, San Francisco-Oxford, Jossey-Bass Publishers.

Shultz, D., Shultz, S. E. (1986), Psychology and industry today, New York, Macmillan Publishing Company.

Srića, V. (2008), Od poduzeća temeljenog na strahu do zdravog poduzeća. 1. međunarodni kongres "Era nove ekonomije i novih zanimanja: Stres i mobbing", plenarno predavanje, Split, 7.-9. studenog 2008.

Sušanj, Z. (2002), Organizacijska klima i kultura u okviru modela suparničkih vrijednosti, Zagreb, Filozofski fakultet, doktorska disertacija.

Sušanj, Z. (2005), Organizacijska klima i kultura, Jastrebarsko, Naklada Slap.

Šegotić, L., Jaković, D., Sušanj, Z. (2006), Istraživanje organizacijske klime i zadovoljstva poslom u hrvatskim poduzećima: Prikaz HROK projekta. Zagreb: AT ADRIA d. o. o., Usmeno priopćenje na 14. godišnjoj konferenciji hrvatskih psihologa, Vodice, 25.-28. listopada 2006.

Šverko, B. (1991), Značenje rada u životu pojedinca: radne vrijednosti, važnost rada i otuđenje. U: V. Kolesarić, M. Krizmanić, B. Petz (ur.). Uvod u psihologiju-Suvremena znanstvena i primijenjena psihologija (str. 17-56), Bjelovar, Grafički zavod Hrvatske.

Templar, R. (2011), The rules of management: A definitive code for managerial success, International Edition, Prentice Hall Business, Pearson education limited.

Wong, Z. (2007), Human factors in project management: Concepts, tools and techniques for inspired teamwork and motivation, San Francisco, John Wiley \& Sons Inc.

Woolridge, B. R., Minsky, B. D. (2002), The role of climate and socialization in developing interfunctional coordination, The Learning Organization, 9 (1): 29-38.

www. sixseconds.com/ovs.php (Pristupljeno, 2. 07. 2008).

Zvonarević, M. (1989), Socijalna psihologija, Zagreb, Školska knjiga.

Datum prve prijave: $\quad$ 19.08.2012.

Datum prihvatanja članka: $\quad 16.11 .2012$.

\section{Kako citirati ovaj rad?}

Style - APA Sixth Edition:

Bogdanović, M. (2013, 01 15). Organizacijska klima u funkciji unaprjeđenja menadžmenta ljudskih resursa. (Z. Čekerevac, Ed.) FBIM Transactions, 1(1), 1-17. Retrieved from www.meste.org/fbim/FBIM 1 2013/ 01.pdf. doi: 10.12709/fbim.01.01.01.01

Style - Chicago Fifteenth Edition:

Bogdanović, Mario. "Organizacijska klima u funkciji unaprjeđenja menadžmenta ljudskih resursa." Edited by Zoran Čekerevac. FBIM Transactions (MESTE NVO) 1, no. 1 (01 2013): 1-17. 
Style - GOST Name Sort:

Bogdanović Mario. Organizacijska klima u funkciji unaprjeđenja menadžmenta ljudskih resursa [Journal] = Organizacijska klima i menadžment ljudskih resursa // FBIM Transactions / ed. Čekerevac Zoran. - [s.I.] : MESTE NVO, 01 15, 2013. - 1 : Vol. 1. - pp. 1-17.

Style - Harvard Anglia:

Bogdanović, M., 2013. Organizacijska klima u funkciji unaprjeđenja menadžmenta ljudskih resursa. FBIM Transactions, 15 01, 1(1), pp. 1-17.

Style - ISO 690 Numerical Reference:

Organizacijska klima u funkciji unaprjeđenja menadžmenta ljudskih resursa. Bogdanović, Mario. [ed.] Zoran Čekerevac. 1, s.I. : MESTE NVO, 01 15, 2013, FBIM Transactions, Vol. 1, pp. 1-17. 